\title{
Active and Reflective Learning to Engage All Students
}

\author{
Bryan McCoy \\ College of Education, Louisiana Tech University \\ *Corresponding Author: bmccoy@latech.edu
}

Copyright (C) 2013 Horizon Research Publishing All rights reserved.

\begin{abstract}
This article describes how teachers effectively manage learning through active engagement of all students throughout each class period. A case study is presented which demonstrates how students learn through active and reflective engagement with ideas, the environment, and other learners (National Middle School Association, 2010). The case study demonstrates the complex task of facilitating integrated, thematic collaborative learning. The case is based on a middle level classroom, but the concepts can be naturalistically generalized by readers to elementary or secondary settings. The case study can be used with pre-service and in-service teachers in a variety of professional development contexts. It can be useful to help educators differentiate between classroom management and behavior management. This paper advances what is known about managing integrated, thematic learning through connecting the theoretical literature with an actual case where these principles are applied.
\end{abstract}

Keywords Classroom Mangement, Integrated Thematic Instruction, Case Study

\section{Introduction}

In this paper, a classroom case study is presented to demonstrate how active and reflective teaching and learning strategies work as tools for managing classroom learning. This case study can be used with pre-service and in-service teachers in a variety of teacher education and professional development contexts. The case study demonstrates the complex task of facilitating integrated, thematic collaborative learning (National Middle School Association, 2010). The case is based on a middle level classroom, but the concepts can be naturalistically generalized by readers to elementary or secondary settings.

The case takes place in a middle school (students who are 11 to 13 years of age) in a small Southern United States city; however, the concepts described in the article can be applied to students in other settings. The concept of engaging students through integrative, thematic, and reflective activities could enhance teaching and learning in any cultural setting, in any part of the world. Advantages of using these strategies include greater engagement of students which results in deeper thinking and long-term retention of learned concepts. Disadvantages include greater preparation time for educators and the challenge of providing access to multiple learning resources. The challenge of resources can be overcome through access to a library, or through access to the World Wide Web.

\section{Materials and Methods}

The case study is divided into classroom scenes which are introduced and supported by ideas from the teaching and learning literature. This is a nontraditional approach intended to make the research more accessible to pre-service and in-service teachers, while still being useful to the traditional educational research community. The summary and conclusions are presented through the final scene of the case study. The case is presented as a single teaching episode. However, the teaching behaviors described were observed over several periods of observations. The observations were made at a middle level school in the Southern United States. The observations took place following extensive and extended professional development sessions which took place over the course of a full school year. The focus of the professional development was development of thematic curricula integrated with state content standards. The case describes the efforts of one teacher to implement an integrated, thematic unit which incorporates significant choice of topics for learners working in collaborative groups. Important details about the classroom and school context are presented within the case scenario.

This paper advances what is known about managing integrated, thematic learning through connecting the theoretical literature with an actual case where these principles are applied.

The scenario/case begins as the last hour, seventh grade class, enters Mr. M's social studies class. The first scene shows the importance of establishing management routines as students enter the classroom and through routine, immediately engage with their learning for the day. The next scene demonstrates the complexity of the learning within a middle level social studies class involved in an interdisciplinary thematic unit and provides a context for 
understanding the strategies presented in the article. The third scene demonstrates two strategies for teaching new content to diverse middle level learners in ways that make the learning accessible to all. The fourth provides insight into using a learning organizer to help students organize both their time, and their thinking. Scene four further demonstrates how a middle level teacher can facilitate group work by keeping students engaged throughout the allotted work time. Scene five demonstrates methods for providing scaffolding to help students respond to higher order thinking questions. Scene six takes place as students are wrapping up the school day; the scene shows students engaged in self-reflection and again demonstrates the importance of classroom management routines. Finally, scene seven serves to summarize and conclude the article. The scene demonstrates that much of the most important work done managing a classroom takes place before and after the school day through evaluation of student work, planning lessons and curriculum, and through making connections with students, other educators, and families.

Below, students enter a seventh grade classroom and through routine, immediately engage in learning. As they prepare for the day's lesson, they reconnect to yesterday's lesson and begin thinking forward to what they will accomplish today.

Scene 1. As the class enters the room each student picks up a folder from one of four accordion files placed strategically in each of the corners of the room. Each accordion file accommodates $1 / 4^{\text {th }}$ of the alphabet; this arrangement enables all the students to efficiently access their folder before being seated.

As the students find their way to their desks, they note the time left on the countdown timer (http:// www.online-stopwatch.com) projected on the large screen pulled down in the front of the room. As they enter the room, the timer begins with five minutes. This gives the students two minutes to find their folders, and their seats, and three minutes to complete their individual planning. The projected timer has large numbers so students can easily monitor their progress from anywhere in the classroom. When the timer reaches zero it sounds a soft ding which clues students to anticipate a transition to a new activity.

Mr. M uses the folders to collect and then to pass back evaluated student work. In the folders today each student finds both yesterday's and today's learning organizers. Students first review comments from the teacher written on the organizer they completed yesterday and then turn to the organizer for today's class period (see Figure 1.). The organizer (figure 1) was developed by the author. The students know that they have three minutes to complete their planning for today by listing three learning goals on the organizer. While the students write their learning goals Mr. $\mathrm{M}$ completes his attendance report and checks-in with several individual students.

\begin{tabular}{|c|c|c|c|c|c|c|}
\hline \multicolumn{7}{|c|}{ Theme: What is So Special about being an American? } \\
\hline \multirow{2}{*}{$\begin{array}{c}\text { Mini-Lesson } \\
\text { Rights and } \\
\text { Responsibilities } \\
\end{array}$} & \multirow{2}{*}{ Native } & \multirow{2}{*}{ Naturalized } & \multirow{2}{*}{$\begin{array}{l}\text { Resident } \\
\text { Alien }\end{array}$} & \multirow{2}{*}{$\begin{array}{l}\text { Illegal } \\
\text { Alien }\end{array}$} & \multirow{8}{*}{5 Minutes: Plan Your Learning } & $\begin{array}{l}\text { List three learning goals you } \\
\text { want to accomplish today. }\end{array}$ \\
\hline & & & & & & \multirow{3}{*}{ (1) } \\
\hline \multicolumn{5}{|l|}{ Right to vote } & & \\
\hline \multirow{2}{*}{$\begin{array}{l}\text { Right to hold all elective } \\
\text { offices including the } \\
\text { presidency }\end{array}$} & & & & & & \\
\hline & & & & & & \multirow[b]{2}{*}{2.} \\
\hline $\begin{array}{l}\text { Right to the benefits of } \\
\text { public policy (e.g., } \\
\text { welfare, education, } \\
\text { public services) }\end{array}$ & & & & & & \\
\hline \multicolumn{5}{|l|}{$\begin{array}{l}\text { Right to the protection of } \\
\text { the U.S. government }\end{array}$} & & \multirow[b]{2}{*}{3.} \\
\hline $\begin{array}{l}\text { Responsibility to } \\
\text { demonstrate loyalty to } \\
\text { the U.S. government }\end{array}$ & & & & & & \\
\hline \multicolumn{5}{|c|}{$\begin{array}{l}\text { Describe one idea you encountered during this time which is } \\
\text { important enough to share with your peers; why is it important? }\end{array}$} & 15 Minutes: Work in Groups & $\begin{array}{l}\text { Describe One idea you } \\
\text { encountered during this time } \\
\text { which you want to learn more } \\
\text { about; why do you want to } \\
\text { learn more? }\end{array}$ \\
\hline
\end{tabular}

Figure 1. Theme: What is So Special about being an American? @ 2012 Dr. Bryan McCoy 
When the countdown timer dings zero he says "Counting from three ... three . . two . . . one . . zero." After he reaches zero, two or three students are still quietly talking so he calmly waits, counting to himself - one Mississippi . . . two Mississippi ... three Mississippi. He knows that if he allows a reasonable wait time the last students will likely get quiet. He counts to himself to assure that he indeed waits three seconds - which sometimes seems to him like an eternity. The wait time works, and after three seconds, all students are silent, focused and ready to transition.

\section{Engaging Teaching Is Complex}

Adolescents learn best through active engagement with ideas, the environment, and other learners (National Middle School Association, 2010). Teachers of middle level students use multiple learning and teaching approaches that respond to student diversity (National Middle School Association, 2010). Middle level classrooms are complex and dynamic environments where individuals and small groups of students simultaneously engage in a wide variety of tasks. The developmental diversity present in every middle grade classroom makes gearing curriculum to each student's level of understanding challenging (National Middle School Association, 2010). The next scene demonstrates the complexity of the learning within a middle level social studies class involved in an interdisciplinary thematic unit and provides a context for understanding the management strategies presented in this article.

Scene 2. Mr. M is a member of a seventh grade teaching team. The team includes three core teachers, a special education teacher, a music teacher, an art teacher, and a health and P.E. teacher. The three core teachers have a daily shared planning period and have worked together to develop an interdisciplinary thematic unit. The school is in a Southwestern state and has a diverse population with a high percentage of immigrants who are primarily from Mexico and Central America. The current thematic unit is called Transitions. In Mr. M's social studies class, the focus this week is on rights and responsibilities of citizens.

Mr. M's last hour class is divided into seven groups ranging in size from two to four students. Each group has developed a unique topic and project related to the overall theme and class topic. One group of students is very interested in learning more about the process of becoming an American citizen. They are creating a short documentary video, featuring interviews with parents who are either new citizens or are currently working toward citizenship. Another group is investigating paying taxes. They have gathered paycheck stubs (with the names redacted), and they are creating a multimedia presentation which follows the money trail of paycheck deductions. They are connecting the deductions to the legislation that necessitates the deduction and investigating where the money actually goes after it leaves the paycheck. A third group is investigating the idea of political efficacy; they want to know if voting really matters. They are developing a survey to gather information for an article they are writing and hope to have published in the local newspaper. The other four groups are similarly engaged in projects which they have developed.

\section{Engaging Teaching Accommodates All Students}

To maximize engaged learning, teachers should introduce important new content at some point in the class period nearly every day. The new content can be part of a carefully crafted scope and sequence or it might stem from questions identified through individual or small-group investigations. Either way, the content should be connected to standards. A societal concern of thematic curriculum is that necessary content might be overlooked as students explore individualized projects or ideas of interest (Vars \& Beane, 2000). Making certain to teach standards based content each day can alleviate trepidation for parents, administrators and even for students who are focused on high-stakes tests. Vars and Bean (2000) recommend involving students in the process of integrating standards based lesson. Such involvement engages learners because it develops critical thinking, demonstrates that student ideas are valued, and helps students to see that education is a matter of serious concern for our entire society (Vars \& Bean, 2000).

Teaching standards based content to diverse middle level learners requires teaching in ways that make the learning accessible to all. When lessons are presented at either a too advanced or too simple level, learners can become frustrated and disengage from learning (Holton \& Clark, 2006). Making learning accessible to all students can be thought of as teaching within each student's zone of proximal development (Borthick, Jones, \& Wakai, 2003), accommodating diverse learners (Burke, Hagan, \& Grossen, 1998), providing scaffolding for all learners (Holton \& Clarke, 2006), or as creating multiple paths of learning (Nichols, 2010). All four of these concepts involve meeting learners where they are. New and challenging content presented in ways that make the learning accessible to each student will interest motivate, and engage learners (Kraft, 2010).

In the following scene, the teacher presents new content through a mini-lecture which is directly connected to both state frameworks and to the thematic topic. Mr. M provides scaffolding for learners with the chart of rights and responsibility which is part of the learning organizer previously introduced (see Figure 1). Following his presentation he provides additional learning support through structured peer-to-peer interactions.

Scene 3. Mr. M directs the students' attention to the learning organizer (see Figure 1.) and instructs them to complete the table about rights and responsibilities of citizens while he presents his mini-lecture. He walks them through the table instructing them to fill in each cell with either yes or no. When he has completed his 10 minute 
presentation he says, "When I say so and not before, I want you to get with a partner sitting next to you to compare your tables. If you find any inconsistencies, talk them out with your partner and see if you can resolve them. I will give you two minutes to work on this. Okay, go ahead and begin."

Mr. M clicks the stopwatch which he always carries in his pocket connected to a watch chain. When the stopwatch indicates that two minutes are up he says, "counting from three ... three ... two . . one . . zero." Just as during the previous transition, two students are still talking quietly after he completes the countdown. As before, he silently counts down three seconds of wait time; this time the students continue to talk, so he calmly walks toward the two talking students. As soon as the two become aware that he is focused on them and coming toward them, their conversation ends and he continues. "Did anyone discover any inconsistencies that they were unable to resolve?" One student exuberantly waves his hand. Mr. M calls on him. "Yes Sir." The student responds, "We found one we had different but we asked someone else and now we have it figured out." Mr. M responds, "Thank you. . . I am glad that you were able to figure it out on your own.... Please tell us a little more about the inconsistency you found and how you resolved the issue."

\section{Engaging Teaching is Carefully Structured}

Frequently, middle level teachers use ineffective patterns of structuring class time (Palumbo \& Sanacore, 2007). A common ineffective pattern is to divide the class into two segments. During the first segment, the teacher presents content, assigns readings, or provides directions. During the second segment, the students work to complete assigned tasks. When this pattern is used students often complete the day's assignments prior to the end of the class period. When students finish their school work before the class time has expired, students may become bored or disruptive (Feldman, 2003), and learning opportunities may be lost.

One effective pattern of structuring class time is to break instruction into smaller teaching and activity sets and to intersperse each set with higher order thinking and reflective questions (Haydon, Borders, Embury, \& Clarke, 2009). This strategy shifts the focus back and forth between teacher-centered whole group instruction and more student-centered, small group learning. Each time the class transitions to a teacher-centered mode, students are first challenged to think deeply about the learning they have so far done, and then refocused to continue on with small group work. When transitions are handled efficiently, this approach can keep lost learning time in check and provide more learning for students (Feldman, 2003).

\subsection{Time Management Strategies}

The time for independent or small group tasks should be short enough that students stay engaged until the teacher transitions back to a whole group focus. If activity sets are shorter, and students know they are accountable to report on their learning progress, students are more likely to stay engaged throughout the allotted independent work time. This may seem at odds with developmental characteristics of adolescents including their wide range of intellectual development (National Middle School Association, 2010). Indeed, students will vary widely in the complexity, quality, and quantity of work they complete in a given time frame. The idea presented here is not that students should reach the same or even similar points in their leaning in the same amount of time. The idea is that through thoughtfully structuring the class, students will have a greater likelihood of staying engaged throughout the entire class period (Sanford \& Evertson, 1983). If there are still times when students perceive that they are finished, this period of time can be shortened.

Allow a reasonable time for completion of a task, and then carefully monitor student progress. As students complete the task before the time is up, reengage the students. One strategy is to check the work of students who finish early; if their work is done well, you can ask them to assist other students. If their work should be improved, you can give feedback and specific redirection.

\subsection{Learning Management Strategies}

A strategy which supports time management is using a learning organizer (see Figure 1.). Learning organizers provide roadmaps for students to follow from the introduction of the lesson through the conclusion. When students know where they are and where they are going in the lesson, they are less likely to mentally stray, and more likely to stay engaged. As seen in the classroom scenario, the learning organizer can be as simple as a table that provides information, writing prompts, and blank space where students write their responses.

The completed organizer should be collected at the end of each class period. It is important for the teacher to provide meaningful feedback and return the graded organizer at the beginning of the very next class. This reinforces the importance of the tasks associated with the organizer and provides individualized feedback and direction (Black \& William, 2010). Prompt, meaningful feedback lets students know that their work is important. When students realize class work is important they are more engaged. The following scene shows the teacher using the learning organizer to help students organize both their time and their thinking. Mr. M facilitates group work by keeping students engaged throughout the allotted work time.

Scene 4. Mr. M directs the students back to the learning organizer and says, "Please look at the prompt on the organizer and read it silently as I read it aloud. Describe one idea you encountered during this time which is important enough to share with your peers. Why is it important? Keep this in mind as you are working in your groups. I will 
give you a couple minutes to write your answer after the fifteen minute group time is up. Are there any questions which the whole group needs to hear?" There are no hands raised or questions so he continues, "I will check-in with each group and see how you are doing, so unless you have a burning issue for the whole class please go ahead now and get started."

Mr. M waits just a brief minute for the groups to get started and then sets the countdown timer for fifteen minutes. During the fifteen minute period he circulates making certain to connect with each group. The group working to link paycheck deductions to legislation asks for help. They are wondering if the paychecks they are working with are typical. Mr. $M$ asks the group where they think they might find information about average incomes in their community. The group comes up with the idea of the census and then Mr. $\mathrm{M}$ helps them to find recent census data online.

Two students from another group appear to be socializing more than learning. Mr. M asks the two to share with him the progress of their work. He discovers that the two have completed work on their video and are waiting while the computer renders their project. He asks the two boys, who he knows to be quite computer savvy, to see if they can help the group working with the online census data until their video is finished.

\section{Engaging Teaching Facilitates Higher Order Thinking}

In the classroom scenario Mr. M structures the class giving students blocks of time for group work and then transitioning to higher order thinking questions designed to help students think about their learning process. Generally, questions presented to the whole class should be structured to engage every student. Such questions should allow students opportunities to connect what they are learning to real life (National Middle School Association, 2010) and help students answer questions they have about themselves, the curriculum, and the real world (National Middle School Association, 2010).

If students are working on a wide variety of topics and tasks as in this scenario, an example of an appropriate higher order thinking question to pose to the whole class is: Reflect on the learning you have done over the last fifteen minutes. What is one idea which you believe is important enough to share with all of your peers? Why is it important? In the scenario, after posing a question to the whole class, and allowing appropriate think time, Mr. M asks each student to write a response. If a question is important enough to pose to the entire class, it is important that all students not only have opportunity to respond to the question but that all students are held accountable for providing a response.

Student responses to carefully planned thinking questions form the basis for formative assessments that promote quality learning and provide continuous, authentic, and appropriate evidence about every student's learning progress (National Middle School Association, 2010).Through such carefully constructed questions, as the one described, students can strengthen both thinking and writing skills.

\subsection{Scaffolding Strategies}

It is important for the teacher to provide scaffolding (Holton \& Clark, 2006) for students who need extra support so that students experience some level of success in responding to questions. In the next scene, after students write a response to a question, Mr. M has them share with a partner. Sharing with a partner is a form of scaffolding and one way to provide students the support necessary to answer open ended questions. It is also an opportunity for important peer interactions which structure avenues for young adolescents to form positive and healthy relationships with their peers (National Middle School Association, 2010).

In scene five, Mr. M facilitates peer sharing and works one-on-one with a student providing scaffolding to help the student think through the question.

Scene 5. He continues to monitor and assist the groups until the timer counts down to zero and dings. Mr. M says "Counting from seven." He chooses a larger number for this transition because the groups are actively engaged in a variety of activities. He wants to allow time for them to naturally come to a point where they can pause for a transition. He continues slowly “. . Seven. . . Six ....” When he reaches zero all the students are quiet and focused on him. "Okay, now I will give you two minutes to go back to your organizer and make sure each of you has written your important idea." He clicks his stopwatch.

He observes the class carefully looking for signals that individuals are struggling to come up with a response. He notices a student who after about a minute still has nothing written. He approaches the students and asks "Tell me what you worked on today in your group." She responds, "You know, we looked up average salaries at the Census Bureau." Mr. M replies, "Did you find that to be important information?" The student's "ah ha" moment was obvious to $\mathrm{Mr} . \mathrm{M}$ as she began to write her response.

After two minutes, he counts down from three, and then instructs the class to share what they have written with a neighbor sitting near them. He reminds them that they can write more or change what they have written as their thinking changes through talking with a neighbor. As the dialogue winds down, he again counts down from three. He then asks for volunteers to share their important idea with the whole class. He calls on a student who replies, "We learned about the average incomes of workers in our state." Mr. M prompts her, "Talk a little more about what you learned." The student becomes more animated as she recounts details about the wide range of salaries and the surprisingly low median salary in their area. He calls on three additional individuals to share and then asks, "Is there anyone else who has a burning desire to share with the class?" One more student raises her hand and shares her important idea. 


\subsection{Assessment Strategies}

Self-reflection provides opportunity for students to think about their own thinking and their own progress (Holton \& Clark, 2006). Self-reflection allows students to honestly evaluate their own engagement with learning. When self-reflection is as an important part of a course it provides self-awareness of students' efforts and helps them to associate their learning efforts with the evaluation and grades they will ultimately receive for their work (Maday, 2008). The importance of self-assessment and self-reflection is discussed in This We Believe (National Middle School Association, 2010) as follows:

In developmentally responsive middle schools, assessment procedures also reflect the unique characteristics of young adolescents. Assessment should emphasize individual progress rather than comparison with other students and should not rely on extrinsic motivation. The goal is to help students discover and understand their own strengths, weaknesses, interests, and aptitudes. Student self-assessment helps develop a fair and realistic self-concept. (p. 26)

An example of an appropriate self-reflection prompt for any class is: Think about your learning today, and using a scale from one through ten with ten being the best, rate the quality of your work. Then, explain why you chose the rating you selected. Additionally you can prompt: describe something you did and/or learned well today and describe something that still poses a challenge for you. It is very important for teachers to thoughtfully respond to students' self reflections. Thoughtful written dialogue helps connect teachers and students and shows students that their work is important. Many students value written responses to their work even more than they value grades.

In the next scene Mr. M uses self-reflection to provide closure for the lesson. We again see the value of routine in facilitating management as the students, without being prompted to do so, put away their folders before exiting the classroom.

Scene 6. Following the group work, Mr. M directs the students back to the organizer to the final section which is the prompt for self-reflection. The students have gone through the routine of using the graphic organizer many times before. Each organizer is different than the one before but they all follow a similar format. The students know that the self-reflection is important. Through established routine the students know that when they are finished with their self-reflection that they are to show that they are done by placing the organizer back into the folder, closing the folder on their desk, and making eye contact with Mr. M.

When Mr. M sees that nearly all the students are finished, he asks the students to talk with a neighbor about what they thought was the most important thing they learned or accomplished today and what they think they might learn about tomorrow. After allowing time for peer sharing, he allows several students to share with the whole class. He then tells them he is eager to meet again tomorrow because he is excited about the progress each of the groups is making and then dismisses the class. After the students are dismissed the students return their folders to the respective accordion files before leaving the classroom. Several students linger, eager to discuss with Mr. M more detail about their plans for class tomorrow.

\section{Summary and Conclusions}

The scene serves to summarize and conclude the article. The scene demonstrates that much of the most important work done managing a classroom takes place before and after the school day through evaluation of student work, planning lessons and curriculum, and through making connections with students, other educators, and families.

Final Scene. Mr. M follows the last lingering student into the hall. Their conversation continues as they walk together; the student heading for intramural basketball practice and $\mathrm{Mr}$. $\mathrm{M}$ to the office to check to see if he has any messages. He is going to spend the fifteen minutes before his 3:30 team meeting making positive phone contacts with parents. He cycles through a list making at least three positive contacts each day. It takes him thirty school days to make a positive contact about each student. Frequently when he calls there is no answer, but he leaves an upbeat, positive message, along with his home phone number so calls can be returned. He is able to cycle through his rosters three or four times each school year. Students almost always mention the phone calls the following day. He finds that students show a little boost in their motivation following a positive home contact. He also uses this time to make any special contacts for exceptional behavior and achievement - both positive and negative.

After the phone calls he goes to the media center and meets up with the other interdisciplinary team members. The team does most of their planning during their shared planning period during the school day, but they find that a brief, daily after school meeting is very useful to take care of things which come up during the school day. During the meeting today they first discuss a student who is hospitalized and decide that they will collaborate to put together a home-study packet. Mr. M brings up a girl in his fifth hour class who was a little out-of-sorts today. One of the team members shares that Mom had contacted her to let her know that the girl's father had gone to jail and that the girl was taking it pretty hard. They decide that they would not bring up the situation with the student directly, but that they would each make special efforts to connect with the student by simply asking her about her day. They also decided to write a referral for the girl to see the school counselor.

Mr. M shares that his students are at the point in their projects where they could really use some extended time, and asks the others if they are making similar progress in their classes. All agree that it would be beneficial, at this point, to use their extended class schedule the following week. They find that students tend to need more time as they become 
more deeply involved in their thematic projects. The school does not ring bells during the school day, and teams have flexibility in scheduling their core classes as long as they meet scheduled obligations such as lunch and special classes.

Following the team meeting, Mr. M returns to his classroom to wrap up the day and prepare for tomorrow. Each day he responds in some way to all students' work because he knows how much the students value his comments, and he sees daily how it serves to motivate and engage his students. Although it may seem a little elementary, Mr. M puts stick-on gold stars rather than a letter grade on daily work. With ninety students he can't give in-depth feedback to each student each day, because he simply does not have the time. His strategy is to every day give in-depth feedback to one of his three classes and to just provide a positive, encouraging note and stick-on stars to the other two classes. This way each student receives in-depth feedback every three days. Many students proudly collect the stars on the back of their folders. He believes that feedback and stars are more meaningful than a letter grade and would like to be able to use this strategy for all evaluations, both summative and formative. But the administration still insists on letter grades, so he gives grades on final projects and tests, and gives feedback and stars on daily work. The other team members take the same approach. They find that the more they can be consistent with their learning management and classroom routines the better their students succeed.

As he reads and comments on his students' work, he reflects on how things went today. He is particularly excited about a couple of the group projects. One group noticed the similarities between new immigrants and new students who transfer from another school. They are developing a new student packet including a test patterned after a citizenship test. They are also developing a swearing in ceremony to help students really feel like they belong in the class. Another group is investigating the problem of immigrant families being split apart when only some family members are able to move to the States. As he reviews this group's work, he remembers that they are writing letters to the American embassy in Mexico City because one of the student's mothers goes there each week and waits in a long line trying to get a visa to come to America to rejoin the rest of her family. In his feedback, he recommends that they might also write letters to their representatives in Congress and perhaps, even to President Obama.

When he is finished with the student work he goes to his lesson plan for tomorrow. As he reviews his plan he decides to add a mini-lesson about how to contact local, state, and national political representatives. He also decides to add a group sharing activity in place of his planned self-reflection activity. He will ask each group to present three things they have learned, three things they want to learn more about, and one problem they are still working to solve. He is adding this activity because there are groups in each class struggling a little at this point in their projects. The small group mini-presentations will give each group a chance to receive feedback and support from their classmates and a chance to take stock of their group process.

He finishes his learning organizer for tomorrow and sends it to the printer in the office to print out ninety copies. He goes back to his lesson plan and adds comments in the margins to remind him how things went today. He finds this professional self-reflection to be useful and sees it as a process similar to the self-reflection he requires from his students. As he reflects on today's classes, he plans on how to approach tomorrow to make it even better than today. All-in-all things went well today but he did have a number of students who need to work harder and a couple of whole groups who seem to be struggling. He writes a list of student names to remind himself tomorrow to be sure to pay additional positive attention to each student on his short list. He also notes a couple of ideas to present to each struggling group to give them a little extra support. It is 5:00 and Mr. M is finished for today. On the way home he stops by the school gym to watch his students as they are finishing up their intramural basketball games. He will be back at school in the morning before 7:00 to be certain he is well prepared to greet each student individually as they enter his classroom promptly at 8:03.

\section{REFERENCES}

[1] Black, P., \& Wiliam, D. (2010). Inside the black box: Raising standards through classroom assessment. Phi Delta Kappan, 92(1), 81-90.

[2] Borthick, A., Jones, D., \& Wakai, S. (2003). Designing learning experiences within learners' zones of proximal development (ZPDs): Enabling collaborative learning on-site and online. Journal of Information Systems, 17(1), 107-134.

[3] Burke, M. D., Hagan, S. L., \& Grossen, B. (1998). What curricular designs and strategies accommodate diverse learners?. Teaching Exceptional Children, 31(2), 34-38.

[4] Feldman, S. (2003). Are you using your time wisely?. Teaching Pre K-8, 33(8).

[5] Haydon, T., Borders, C., Embury, D., \& Clarke, L. (2009). Using effective instructional delivery as a classwide management tool. Beyond Behavior, 18(2), 12-17.

[6] Holton, D., \& Clarke, D. (2006). Scaffolding and metacognition. International Journal of Mathematical Education in Science \& Technology, 37(2), 127-143.

[7] Kraft, M. (2010). From ringmaster to conductor. Phi Delta Kappan, 91(7), 44-47.

[8] Maday, T. (2008). Stuck in the middle: Strategies to engage middle level Learners. Retrieved from http://www.centerforcsri.org/index.php?Itemid=5\&id=551\& option $=$ com_content\&task=view

[9] National Middle School Association. (2010). This we believe: Keys to educating young adolescents. Westerville, $\mathrm{OH}$.

[10] Nichols, P.D. (2010). What is a learning progression? Test 
Measurement and Research Services Bulletin. Retrieved from

http://www.pearsonassessments.com/NR/rdonlyres/.../Bulleti n_12.pdf

[11] Palumbo, A., \& Sanacore, J. (2007). Classroom management: Help for the beginning secondary school teacher. Clearing House, 81(2), 67-70.
[12] Sanford, J. P., \& Evertson, C. M. (1983). Time use and activities in junior high classes. Journal of Educational Research, 76(3), 140-147.

[13] Vars, G.F., \& Beane, J. A. Integrative curriculum in a standards-based world. ERIC Digest. Retrieved from ERIC database. (ED441618) 